\title{
Implementation of Adaptive Curriculum for Children with Special Needs in Inclusive Education Provider Schools in Surakarta
}

\author{
Yuniviana Nur Hari Prajalani; Sunardi; Herry Widyastono \\ Faculty of Teacher Training and Education, Sebelas Maret University, Surakarta, Indonesia \\ http://dx.doi.org/10.18415/ijmmu.v8i10.3090
}

\begin{abstract}
The purpose of this study is to determine the implementation of the adaptive curriculum in inclusive schools in Surakarta. The adaptive curriculum is a curriculum developed to accommodate the needs of children with special needs with various backgrounds and abilities, with the aim that the curriculum pays more attention to the diversity of students and can create learning that is relevant to their abilities and needs. This research was conducted at four inclusive schools in the city of Surakarta, namely SDN Bromantakan, SDN Pajang I, SDN Kartodipuran, and SDN Wiropaten I. The research subjects were teachers who taught at inclusive schools totaling 33 respondents. Data collection techniques used are interviews and closed questionnaires. The data analysis technique used in this study is qualitative data analysis according to Miles and Huberman. This analysis model consists of three steps, namely data reduction, data presentation, and concluding. The findings of this study indicate that teachers at inclusive schools in the city of Surakarta have implemented an adaptive curriculum in the form of duplication, modification, omission, and substitution models, while escalation is not enforced because schools providing inclusive education in the city of Surakarta do not have students gifted and talented.
\end{abstract}

Keywords: Implementation of Adaptive Curriculum; Children with Special Needs; Inclusive School

\section{Introduction}

The implementation of education for Children with Special Needs has received attention from the government. Education for Children with Special Needs is called Special Education. Based on Law no. 20 of 2003 concerning the National Education System in article 32 paragraph (1) it is stated that special education is education for students who have a level of difficulty in participating in the learning process due to physical, emotional, mental, social disorders, and/or have the potential for special intelligence and talent. Special education models can be in the form of segregation education, integration education, and inclusive education. Inclusive education is the newest education system for Children with Special Needs. Inclusive education is an educational service system that includes children with special needs studying together with their peers in regular schools closest to their place of residence (Ilahi, 2013).

The legal basis for implementing inclusive education is stated in the Minister of National Education Regulation No. 70 of 2009 concerning Inclusive Education for Students with Disabilities and Potential Intelligence and/or Special Talents. Based on the regulation, article 1 states that what is meant 
by inclusive education is an education system that provides opportunities for all students who have disabilities and have the potential for intelligence and/or special talents to participate in education or learning in an educational environment together with other students. educated in general. Children with Special Needs who study at schools providing Inclusive Education have the same opportunity to learn. In line with the opinion of Dapa, et al (2007) which states that inclusive education is a service that provides opportunities for all children to get education in public schools with other children.

Inclusive education is a means to realize education for all or education for all. With inclusive education, children with special needs can get equal rights, especially in education. Children with Special Needs study together with other normal children to optimize their potential by using the curriculum, learning facilities, and teaching and learning activities that are adapted to their conditions. Inclusive education is the most effective program in realizing the demands for equal distribution of education for all citizens (Gunarhadi, et al, 2019).

One of the problems of inclusive education is that the current general education curriculum has not accommodated the existence of Children with Special Needs. Teachers tend to still have difficulty in formulating flexible curricula, making Individualized Educational Programs, and in determining goals, materials, and learning methods for children with different abilities (disabled) (Sunardi and Sunaryo, 2011).

The curriculum is a set of plans and arrangements regarding the objectives, content, and learning materials, as well as the methods used as guidelines for the implementation of learning activities to achieve certain educational goals (Sukadari, 2019). The curriculum has a very strategic position because the curriculum is structured to realize educational goals (Sukadari, 2019). Considering and selecting an appropriate curriculum for the management of inclusive classroom learning is a way to achieve the goal of developing students by considering the diversity of students and responding to the needs and abilities of students (Bubpha, Erawan, \& Saihong, 2012).

In the implementation of inclusive education, each child is provided with services according to their specific needs, these services can be reached by making various modifications and or adjustments, starting from the curriculum, infrastructure, learning systems, assessment systems, and educators and education staff. Most of the special assistant teachers in inclusive schools have not been able to adapt the curriculum (Mirasandi, 2019). Teachers adapt the curriculum only to the extent of adapting the materials and learning strategies. According to Gunarhadi, et al, (2019) teachers in inclusive schools are required to know special areas of special education such as identification, assessment, curriculum modification, individual instruction, and evaluation methods. Characteristics of Children with Special Needs in inclusive schools are very diverse, therefore it is necessary to develop an adaptive curriculum to meet the needs of students.

Based on this description, the purpose of this study is to determine the implementation of the adaptive curriculum applied in the Inclusive Education Provider School in the city of Surakarta.

\section{Methodology}

This research is a type of qualitative descriptive research. Qualitative research is research where the researcher is placed as a key instrument, data collection techniques are combined and data analysis is inductive (Sugiyono, 2010). The research was conducted in four schools providing inclusive education in the city of Surakarta, namely SD Negeri Bromantakan, SD Negeri Pajang I, SD Negeri Kartodipuran, and SD Negeri Wiropaten I. The subjects in this study were teachers in inclusive schools, both classroom teachers, subject teachers, as well as special education teachers. The data collection techniques in this study were interviews and the distribution of closed questionnaires with answer choices. 
The data analysis technique used in this research is qualitative analysis according to Miles and Huberman. This analysis consists of three stages, namely data reduction, data presentation, and concluding. In the data reduction stage, the researchers collected information obtained through interviews with the induction coordinator and distributing questionnaires to teachers. At the data presentation stage, the researcher narratively presents the data based on the data that has been obtained with the support of data in the form of diagrams. The third stage is concluding, this stage is the last stage in qualitative data analysis, researchers conclude from the data that has been obtained.

\section{Results and Discussion}

The results of interviews from informants obtained data that the current curriculum uses the 2013 curriculum. The curriculum used in inclusive education essentially uses the national standard curriculum that applies at the school. Teachers have implemented an adaptive curriculum for Children with Special Needs. In adapting the curriculum, teachers experience difficulties in collaborating, namely collaboration between class teachers and special assistant teachers. In the implementation of inclusive education, there must be cooperation from various parties for the creation of education that can accommodate the needs of Children with Special Needs. The division of tasks and collaboration between core teachers and accompanying teachers in inclusive classes makes students feel comfortable and more confident in participating in the learning process (Budiarti \& Sugito, 2018).

There are five models of adaptive curriculum development for Children with Special Needs, including the escalation model, duplication model, modification model, substitution model, and omission model (PKLK, 2011). Based on data from the questionnaire that has been distributed, the following data are obtained:

\section{Escalation Model}

According to the KBBI, escalation means an increase; increase (volume, amount, etc.). The escalation model means the adaptation or adjustment of the curriculum upwards (escalation) for students who have the potential for intelligence and/or special talents. At schools providing inclusive education in the city of Surakarta, data from the four schools showed that most of the teachers had not implemented the escalation model adaptive curriculum. This is evidenced by the statements with yes and no answers, 93.94\% of teachers answered that they did not adopt the escalation model curriculum and $6.06 \%$ of teachers had developed an escalation model curriculum. Some teachers in inclusive schools do not adapt the escalation model curriculum because there are no Children with Special Needs in the special intelligent category and special talents in the school. The teacher also said that the ability to handle Children with Special Needs in the classroom was still experiencing difficulties. The percentage of implementation of the escalation model can be seen in the following pie chart:

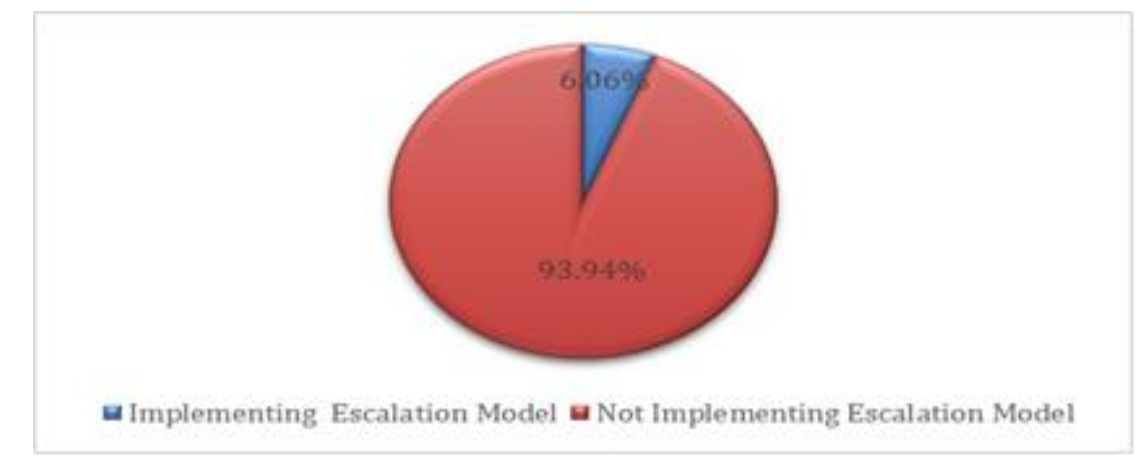

Figure 1. Percentage of Implementation of an Escalation Model (\%) 


\section{Duplication Model}

Duplication means a copy that is identical to the original. The development of a duplication model of the adaptive curriculum means developing and or implementing a curriculum for Children with Special Needs in the same or similar way as the curriculum used for regular students. So the duplication model is a way of curriculum development, where Children with Special Needs use the same curriculum as that used by regular students. The duplication model can be applied to four main components of the curriculum, namely objectives, content, process, and assessment. Based on the data that has been obtained, it shows that $45.45 \%$ of teachers in inclusive schools in the city of Surakarta have developed a duplication model curriculum, while $54.55 \%$ have not developed a duplication model curriculum. The percentage can be seen in the following pie chart:

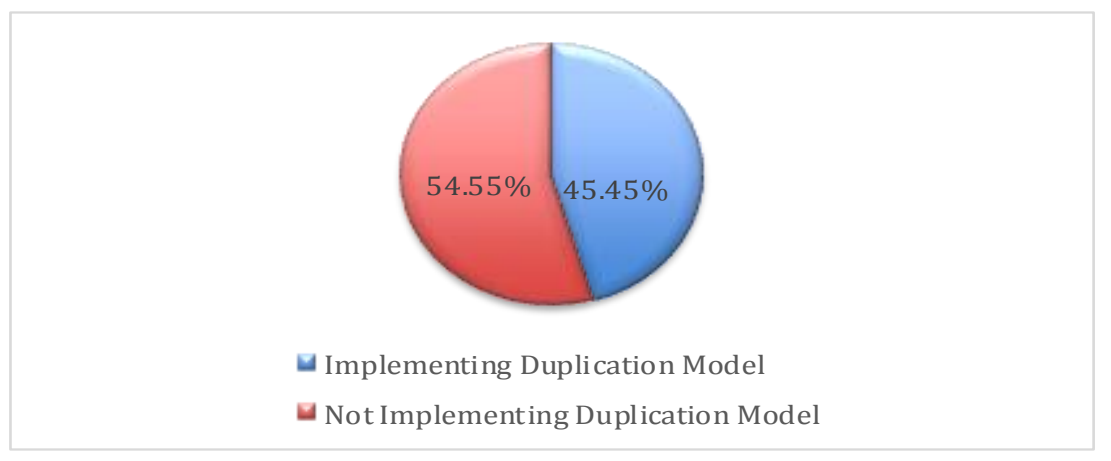

The duplication model is basically that Children with Special Needs continue to use the curriculum according to national standards such as another normal child. Teachers have a reason not to do a duplication model because Children with Special Needs do not have cognitive problems. Curriculum is Duplicated applied to Children with Special Needs who do not have cognitive barriers (Murniati \& Anastasia, 2016).

\section{Modified Model}

Modification means to change or adjust. The development of a modified model of the adaptive curriculum means a way of curriculum development, where the general curriculum that is applied to regular students is changed to suit the conditions, needs, and abilities of Children with Special Needs. Modifications can be applied to four main components, namely objectives, materials, processes, and evaluation/assessment. Thus, Children with Special Needs use a curriculum that is adapted to their conditions, needs, and abilities. Based on the data that has been obtained, it shows that $78.79 \%$ of teachers in inclusive schools in the city of Surakarta have developed a modified model curriculum, while $21.21 \%$ have not developed a modified model curriculum. The percentage can be seen in the following pie chart:

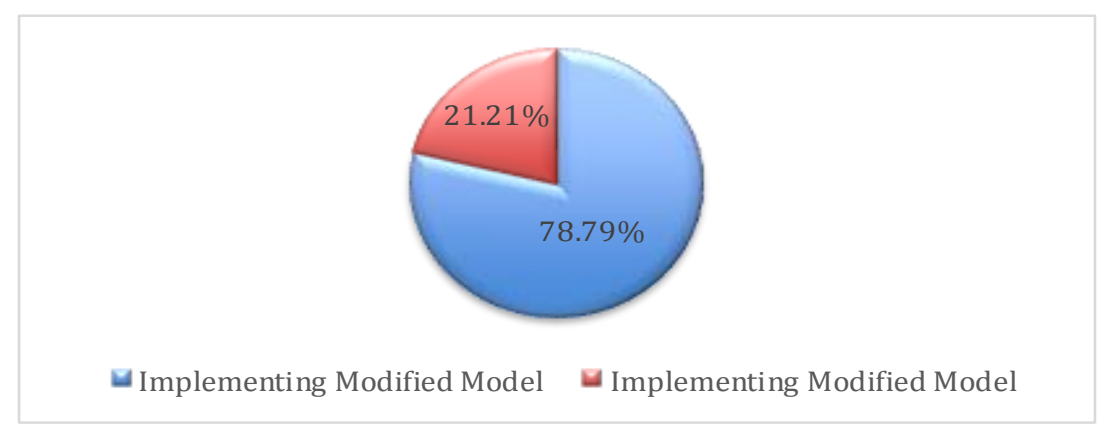

Figure 3. Percentage of Modified Model Implementation (\%) 
The modified model is the most widely used model in inclusive education providers in the city of Surakarta. Other research also shows that $57 \%$ of teachers want the implementation of curriculum development with a substitution model and $43 \%$ want a modified model (Bektiningsih, et.al., 2020). The two models are chosen, namely, the substitution model and the modified model, are considered the most appropriate and most likely to be applied to Children with Special Needs.

\section{Substitution Model}

Substitution means replacing. Substitution model adaptive curriculum development means a way of curriculum development by replacing something in the general curriculum with something else. Replacement is done because it is impossible for Children with Special Needs to be able to do it but can still be replaced with other things that have the same weight as the one being replaced. Substitution models can occur in terms of learning objectives, materials, processes, and assessments. Based on the data that has been obtained, it shows that $75.76 \%$ of teachers in inclusive schools in the city of Surakarta have developed a substitution model curriculum, while $24.24 \%$ have not developed a substitution model curriculum. The percentage can be seen in the following pie chart:

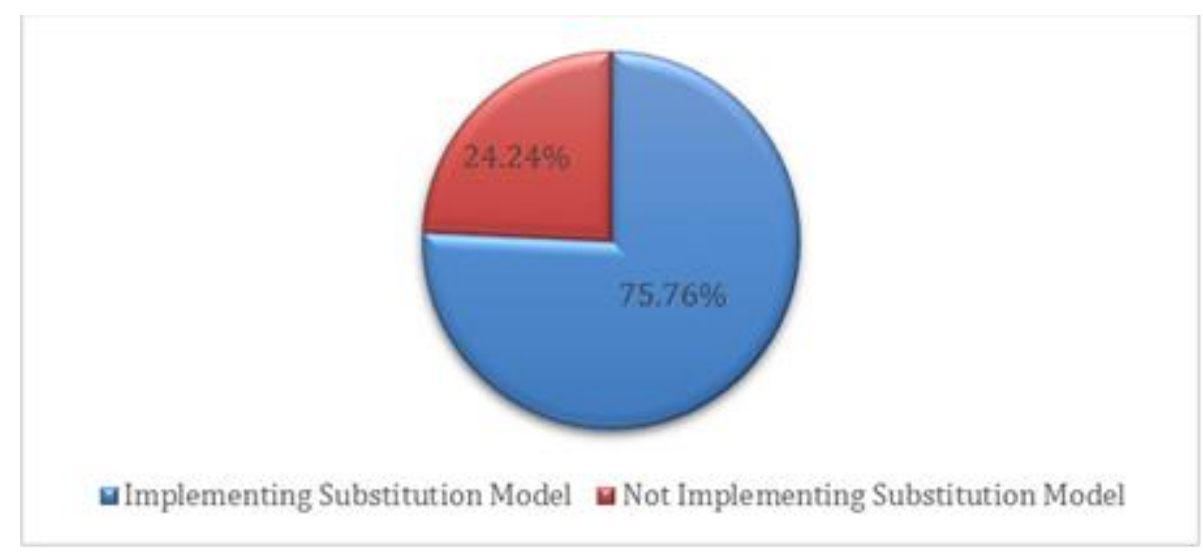

Figure 4. Percentage of Substitution Model Implementation (\%)

Based on previous research shows that the substitution model is a model that is widely applied to Children with Special Needs in inclusive schools. An example of an adaptation of the substitution model is that deaf children in the indicator of retelling the contents of short texts are adapted by rewriting the contents of the text using their own language and the question and answer indicator is adjusted to the teacher writing down the questions and then the students writing the answers (Mirasandi, 2019).

\section{Omission Model}

Omission means eliminating. The development of the omission model adaptive curriculum means a way of curriculum development by eliminating something from the general/vocational curriculum because it is impossible to give children with special needs in inclusive schools. In other words, omission means something that is in the general curriculum but is not conveyed or given to Children with Special Needs in inclusive schools, because it is too difficult or will not be able to be done by Children with Special Needs. Based on the data obtained, it shows that $42.42 \%$ of teachers in inclusive schools in the city of Surakarta have developed an omission model curriculum, while $57.58 \%$ have not developed an omission model curriculum. The percentage can be seen in the following pie chart: 


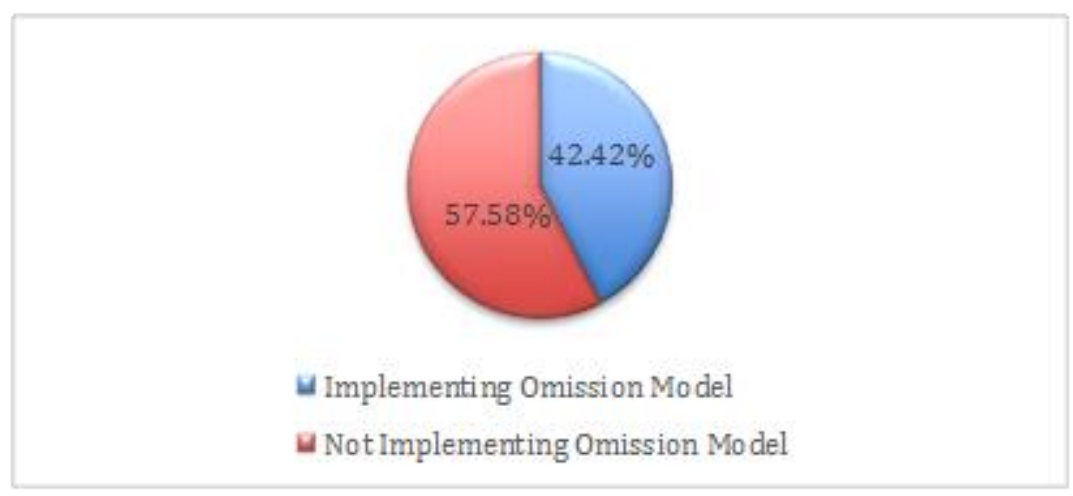

Figure 5. Percentage of the omission model (\%)

Of the five types of adaptive curriculum development models, the implementation does not have to be the same for each component, the adjustment does not have to be the same for all materials. The development of the DMSO model curriculum (Duplication, Modification, Substitution, Omission) adapts to the needs of students (Maghfiroh, 2013). The DMSO model can be stated and clarified in the design of the Individual Learning Program, syllabus, and Learning Implementation Plan (Mukaffa, Taufik, \& Huda, 2017). With the development of an adaptive curriculum, Children with Special Needs in inclusive schools can participate in learning according to their needs to improve their academic achievement. When curriculum modifications are given, students engage in more academic responses (Lee, Wehmeyer, Soukup \& Palmer, 2010).

\section{Conclusion}

The diversity of children with special needs in inclusive schools requires an adaptive curriculum so that the needs of students can be met. There are five models of adaptive curriculum for Children with Special Needs that can be applied in inclusive schools. Teachers at inclusive schools in Surakarta have implemented adaptive curricula in the form of duplication, modification, omission, and substitution models, while escalation is not enforced because inclusive education schools in Surakarta do not have students with special intelligence and special talents. Modification models and substitution models are models that are widely used. The development of an adaptive curriculum can make children with special needs get maximum and optimal learning so that they can improve their academics.

\section{References}

Bubpha, S., Erawan, P., \& Saihong, P. (2012). Model Development for Inclusive Education Management: Practical Guidelines for Inclusive Schools. Journal of Education and Practice, 3 (8) 223-232.

Budiarti, N.D. \& Sugito. (2018). Implementation of Inclusive Education of Elementary Schools: a Case Study in Karangmojo Sub-District, Gunung Kidul Regency. Journal of Education and Learning (EduLearn), 12 (2) 214-223. https://doi.org/10.11591/edulearn.v12i2.8727

Dapa, A. dkk. (2007). Manajemen Pendidikan Inklusi. Jakarta: Departemen Pendidikan Nasional, Direktorat Jenderal Pendidikan Tinggi, Direktorat Ketenagaan.

Gunarhadi., Sunardi., Andayani, T.R., \& Anwar, M. (2016). Pedagogic Mapping of Teacher Competence in Inclusive Schools. Proceedings of ICTTE FKIP UNS 2015, 1 (1) 389-394. 
Ilahi, M.T. (2013). Pendidikan Inklusif Konsep dan Aplikasi. Jogyakarta: Ar-ruzz Media.

Lee, S.H., Wehmeyer, M.L., Soukop, J.H., \& Palmer, S.B. (2009). Impact of Modification on Access to the General Education Curriculum for Students with Disabilities Curriculum. Journal Exceptional Children, 76 (2). https://doi.org/10.1177/001440291007600205

Maghfiroh, L. (2013). Pengembangan Kurikulum model DMSO (Duplikasi, Modifikasi, Substitusi, Omisi) dan Implementasinya dalam Pembelajaran Pendidikan Agama Islam di SMP Galuh Handayani (Penyelenggara Pendidikan Inklusif). Tesis, Program Pascasarjana Institut Agama Islam Negeri Sunan Ampel Surabaya.

Mirasandi, I.S. (2019). Curriculum Adaptation in Learning Student with Special Needs at Inclusive Schools Surakarta City. Indonesian Journal of Disability Studies (IJDS), 6(1) 42- 46. http://dx.doi.org/10.21776/ub.ijds.2019.006.01.6

Mukkafa, Z., Taufik., Huda, M.N. (2017). Pengembangan Model Madrasah Inklusif (Studi Atas Kesiapan dan Model Pengembangan Kurikulum Madrasah Inklusif Mi Al-Hidayah Margorejo Surabaya). Jurnal Penelitian Pendidikan Islam, 12 (1). http://dx.doi.org/10.21043/edukasia.v12i1.2051

Murniarti, E. \& Anastasia, N.Z. (2016). Pendidikan Inklusif Di Tingkat Sekolah Dasar: Konsep, Implementasi, dan Strategi. Jurnal Dimnamika Pendidikan, 9 (1). https://doi.org/10.51212/jdp.v9i1.134

Peraturan Menteri Pendidikan Nasional Nomor 70 Tahun 2009 Tentang Pendidikan Inklusif bagi Peserta Didik yang Memiliki Kelainan dan Memiliki Potensi Kecerdasan dan/atau Bakat Istimewa.

PKLK. (2011). Pedoman Umum Penyelengaraan Pendidikan Inklusif. Jakarta: Kementrian Pendidikan dan Kebudayaan.

Sugiyono. (2010). Metode Penelitian Pendidikan Pendekatan Kuantitatif, kualitatif, dan R\&D. Bandung: Alfabeta.

Sukadari. (2019). Model Pendidikan Inklusi dalam Pembelajaran Anak Berkebutuhan Khusus. Yogyakarta: Kanwa Publisher.

Sunardi \& Sunaryo. (2011). Manajemen Pendidikan Inklusif: Konsep, Kebijakan, dan Implementasinya. JASSI_Anakku, 10 (2), 184-200.

\section{Copyrights}

Copyright for this article is retained by the author(s), with first publication rights granted to the journal.

This is an open-access article distributed under the terms and conditions of the Creative Commons Attribution license (http://creativecommons.org/licenses/by/4.0/). 